\title{
Investigation of the Mechanism of Physiological Tolerance in Lentil (Lens culinaris Medik.) Cultivars under Drought Stress Conditions
}

\author{
Hande Morgil, Yusuf Can Gercek, Mahmut Caliskan, Gul Cevahir Oz* \\ Istanbul Universiy, Department of Biology, Istanbul, Turkey
}

Please cite this article as: Morgil H, Gercek YC, Caliskan M, Cevahir Oz G. Investigation of the Mechanism of Physiological Tolerance in Lentil (Lens culinaris Medik.) Cultivars under Drought Stress Conditions. Eur J Biol 2017; 76(1): 31-5.

\begin{abstract}
Lentil (Lens culinaris Medik.) is valued throughout the world for human and animal nutrition because of its high protein, vitamin, and mineral contents. Lentil production has decreased worldwide due to global warming. Although the physiological parameters of lentil plants have been examined under drought conditions, its tolerance mechanism has not been fully elucidated yet. In this study, lentil seedlings following germination were exposed to drought stress using $15 \%$ polyethylene glycol (PEG) application for 7 days. The untreated control plants were allowed to grow under conditions similar to that of germination. Oxidative stress responses (relative water content, chlorophyll content, $\mathrm{H}_{2} \mathrm{O}_{2}$ formation, lipid peroxidation, and proline accumulation) were compared in leaf samples of experimental and control group plants grown for 7 days under drought stress. Although the physiological and biochemical responses of the cultivars Fırat 87 and Çiftçi were close to each other, proline accumulation, malondialdehyde, and $\mathrm{H}_{2} \mathrm{O}_{2}$ levels were found to increase in the Sultan cultivar. Thus, it can be concluded that Fırat 87 and Çiftçi cultivars are more resistant to drought than the Sultan cultivar.
\end{abstract}

Keywords: Lentil, drought stress, oxidative stress, drought-tolerant, drought-sensitive, physiological tolerance mechanism

\section{INTRODUCTION}

Lentil, one of the earliest known cultivars since the Neolithic period, has a special preference for less soil selectivity, more resistance to cold season, and constancy. It is valued throughout the world for human and animal nutrition because of its high protein, vitamin, and mineral contents. Lentil is a high energy and protein source containing $75 \%$ carbohydrate, $21 \%$ protein, and $4 \%$ fat and also rich in thiamine, iron, phosphorus, and copper (1). There are many lentil varieties registered in a large part of Turkey, especially in the Southeastern Anatolia Region.

Most of the lentil growing countries face a significant decrease in plant growth and yield due to abiotic and biotic stresses. The plants therefore try to cope with different environmental factors. In plants, drought stress is one of the most common environmental factors affecting growth and fertility while causing several metabolic, mechanical and oxidative changes (2). Therefore, identifying the plant species resistant to drought stress and understanding the tolerance mechanisms can play an important role in coping with drought conditions (3). Compared to other cultivated species, although lentil is relatively resistant to drought, severe drought stress experienced during specific developmental periods can cause yield and quality losses.

Due to drought stress, plants that are exposed to osmotic stress accumulate substances known as osmolites that provide continuation of the turgor pressure. Osmotic protectors accumulate in the cytoplasm and large organelles and are virtually absent in the vacuole. Osmotic regulation involves the active accumulation of organic and inorganic substances in the cell, in response to decrease in environmental water potential. The accumulated organic compounds are stable in the cell, are not easily metabolized, and do not have any effect on cellular functions even in the case of accumulation in higher concentrations (2). During drought stress, the relative water content (RWC) of the leaves in plants decreases the rate of photosynthesis (4). It is known that photosynthetic activity is inhibited by drought 
stress because the balance between the amount of light absorbed and the light used by the leaves is impaired (5). Under these conditions, the balance between the formation and the use of electrons in photosystem II is degraded. These photochemical changes in the chloroplasts of plants under drought stress cause the formation of active oxygen derivatives $\left(\mathrm{O}_{2}^{-1}, \mathrm{O}_{2^{\prime}}\right.$ $\mathrm{H}_{2} \mathrm{O}_{2}$, and $\mathrm{OH}^{*}$ ) in tissues (6). Sairam et al. (7) investigated the role of antioxidant systems in wheat varieties under drought stress conditions. Drought increased $\mathrm{H}_{2} \mathrm{O}_{2}$ accumulation and lipid peroxidation in plants while reducing ascorbic acid concentrations. Several studies have shown that drought stress causes an increase in proline which is an important parameter in determining the extent of tolerance to drought (8-11).

We conducted an experiment using lentil cultivars to determine the changes in physiological responses caused due to drought stress. Measurements included plant height, total chlorophyll, proline and $\mathrm{H}_{2} \mathrm{O}_{2}$ contents, RWC, and lipid peroxidation using malondialdehyde (MDA) content. All the parameters are measured from leaf samples of control and experimental group plants grown for 7 days under drought stress.

\section{MATERIALS AND METHODS}

\section{Seed Germination and Drought Stress Application}

Lentil seeds (Lens culinaris Medik.) were supplied by the Southeastern Anatolia Agricultural Research Institute (cultivars Fırat87, Çiftçi, and Sultan).The seeds were screened for size homogeneity and surface-sterilized for $15 \mathrm{~min}$ in $5 \%(\mathrm{w} / \mathrm{v})$ $\mathrm{Ca}(\mathrm{OCl})_{2}$ followed by rinsing and soaking in distilled water. Lentil seeds were grown in perlite medium for 7 days and irrigated with $0.5 \%$ Hoagland nutrient solution $\left(5 \mathrm{mM} \mathrm{KNO}_{3}, 5 \mathrm{mM}\right.$ $\mathrm{Ca}\left(\mathrm{NO}_{3}\right)_{2^{\prime}}, 1 \mathrm{mM} \mathrm{MgSO}_{4^{\prime}} 5 \mathrm{mM} \mathrm{KH}_{2} \mathrm{PO}_{4^{\prime}} 0.1 \mathrm{mM}$ FeEDTA, $46 \mathrm{mM}$ $\mathrm{H}_{3} \mathrm{BO}_{3^{\prime}}, 4.5 \mathrm{mM} \mathrm{MnCl}_{2^{\prime}} 3.8 \mathrm{mM} \mathrm{ZnSO} 4^{\prime}, 0.3 \mathrm{mM} \mathrm{CuSO}_{4^{\prime}} 0.1 \mathrm{mM}$ $\mathrm{NH}_{4} \mathrm{MoO}_{7}$ ) (12). A mixture of polyethylene glycol (PEG, 15\%) dissolved in $0.5 \%$ Hoagland nutrient solution was applied to 7-day old seedlings. All experiments involving germination and plant growth were carried out at a temperature of $25 \pm 2^{\circ} \mathrm{C}$ in the climate chamber with a constant relative humidity set at $65 \pm 5 \%$. Light intensity was set to 14,500 lux ( $16 \mathrm{~h}$ day/ $8 \mathrm{~h}$ dark). The experiment lasted for 14 days that included 7 days each for germination and drought stress. The entire study was performed in three biological and technical replicates.

\section{Relative Water Content Determination}

Young leaf samples taken at the end of the stress stage were weighed immediately to determine the fresh weight (FW), and samples were immersed in distilled water for $4 \mathrm{~h}$ to determine the turgor weight (TW). These samples were then dried at $60^{\circ} \mathrm{C}$ for $24 \mathrm{~h}$ in a circulating air dryer to determine the dry weight (DW) (13). RWC of the leaves was calculated using the following formula:

RWC $(\%)=[(F W-D W) /(T W-D W)] \times 100$

\section{Chlorophyll Determination}

The leaves were extracted using $80 \%$ acetone, and the absorbance was measured at $400-750 \mathrm{~nm}$ using a microplate reader
(Biotek Epoch ${ }^{\mathrm{TM}}$ Microplate Spectrophotometer). Chlorophyll was expressed on an FW basis $(\mu \mathrm{g} / \mathrm{g})$ using the following formula (14):

Chlorophyll $a(\mu \mathrm{g} / \mathrm{g})=\left(11.6 \times \mathrm{A}_{665}\right)-\left(0.14 \times \mathrm{A}_{645}\right)-\left(0.14 \mathrm{~A}_{630}\right) \cdot \mathrm{v} / \mathrm{V} . \mathrm{I}$

Chlorophyll $b(\mu \mathrm{g} / \mathrm{g})=\left(20.7 \times \mathrm{A}_{645}\right)-\left(4.34 \times \mathrm{A}_{665}\right)-\left(4.42 \mathrm{~A}_{630}\right) . \mathrm{v} / \mathrm{V} . \mathrm{I}$

\section{Lipid Peroxidation Determination}

Lipid peroxidation in plants is expressed as MDA content. Based on the method of Sairam and Saxena (15), approximately 100 $\mathrm{mg}$ of plant parts was homogenized with $2 \mathrm{~mL}$ of $5 \%$ trichloroacetic acid (TCA). The extracts were centrifuged at room temperature at $10,000 \mathrm{rpm}$ for $15 \mathrm{~min}$, and $1 \mathrm{~mL}$ of the supernatant was added to a mixture of $20 \mathrm{~mL}$ of TCA and $4 \mathrm{~mL}$ of $0.5 \%$ thiobarbituric acid solution; this mixture was incubated for $30 \mathrm{~min}$ at $96^{\circ} \mathrm{C}$, rapidly cooled in an ice bath and centrifuged at 10,000 $\mathrm{rpm}$ for $10 \mathrm{~min}$. The absorbance was measured at $532-600 \mathrm{~nm}$ on a spectrophotometer (Biotek Epoch ${ }^{\mathrm{TM}}$ ) and expressed as $\mu \mathrm{mol} / \mathrm{mg} \mathrm{FW}$.

\section{Proline Determination}

Approximately $0.5 \mathrm{~g}$ of the leaves sample was homogenized with $10 \mathrm{~mL}$ of $3 \%$ sulfosalicylic acid and filtered using a Whatman No.2 filter paper. Proline concentrations in the extract were spectrophotometrically determined as reported by Bates et al. (16).

\section{$\mathrm{H}_{2} \mathbf{O}_{2}$ Determination}

Based on the method of Teranishi et al. (17), approximately 500 mg of plant tissue was homogenized in cold buffer containing 5 $\mathrm{mL}$ of $3 \%(\mathrm{w} / \mathrm{v})$ TCA. The homogenate was centrifuged at 12,000 rpm for $15 \mathrm{~min}$, and $0.5 \mathrm{~mL}$ of the supernatant was added to a mixture of $0.5 \mathrm{~mL}$ of $100 \mathrm{mM}$ potassium phosphate buffer $(\mathrm{pH}$ 7.0) and $1 \mathrm{~mL}$ of $1 \mathrm{M}$ potassium iodide solution. The absorbance was measured at $415 \mathrm{~nm}$ on a spectrophotometer (Biotek Ep$\mathrm{och}^{\mathrm{TM}}$ ) and expressed as $\mu \mathrm{mol} / \mathrm{mg} \mathrm{FW}$.

\section{Statistical Analysis}

Values presented in Table 1-3 are expressed as mean \pm standard deviation (SD) of three biological and technical replicates. Student's t-test (two-tailed) was done to analyzed statistical differences between groups using GraphPad Prism 5 software. $p$ values less than 0.05 were considered to be significant.

\section{RESULTS}

Drought is one of the most important factors limiting lentil production in arid and semi-arid regions. Relationships among relative water, proline, chlorophyll, lipid peroxidation, and $\mathrm{H}_{2} \mathrm{O}_{2}$ contents were determined to identify whether those physiological parameters could be used as the genotypic selection criteria for drought tolerance. The above-mentioned parameters for the lentil cultivars Fırat 87, Sultan, and Çiftçi are shown in Table $1-3$, respectively.

In the case of Firat 87 cultivar, the plants in the $7^{\text {th }}$ day stressed group showed a significant growth in stressful condition compared to control group $\left({ }^{a} p<0.05\right)$. The RWC ratio of the plants 
Table 1. Changes in morpho-physiological parameters in Lens culinaris cultivar Fırat 87

\begin{tabular}{|c|c|c|}
\hline Parameters & Control & $\begin{array}{c}7^{\text {th }} \text { day stressed } \\
\text { group }\end{array}$ \\
\hline Plant height $(\mathrm{cm})$ & $22.9 \pm 0.13$ & $19.03 \pm 0.15^{\mathrm{a}}$ \\
\hline RWC (\%/plant) & $85.22 \pm 0.21$ & $82.53 \pm 0.16$ \\
\hline $\mathrm{Chl} \mathrm{a}(\mu \mathrm{g} / \mathrm{g} \mathrm{FW})$ & $3.18 \pm 0.04$ & $3.21 \pm 0.07$ \\
\hline $\mathrm{Chl} \mathrm{b}(\mu \mathrm{g} / \mathrm{g} \mathrm{FW})$ & $3.68 \pm 0.05$ & $3.71 \pm 0.06$ \\
\hline Proline content ( $\mu \mathrm{mol} / \mathrm{g} \mathrm{FW})$ & $0.368 \pm 0.16$ & $3.87 \pm 0.15^{b}$ \\
\hline $\mathrm{H}_{2} \mathrm{O}_{2}$ content $(\mu \mathrm{mol} / \mathrm{g} \mathrm{FW})$ & $0.016 \pm 0.16$ & $0.018 \pm 0.12$ \\
\hline MDA content $(\mu \mathrm{mol} / \mathrm{g} \mathrm{FW})$ & $6.62 \pm 0.05$ & $6.72 \pm 0.09$ \\
\hline \multicolumn{3}{|c|}{$\begin{array}{l}\text { All the measured parameters from leaf samples of control and } \\
\text { experimental group plants grown for } 7 \text { days under drought stress are } \\
\text { given below. Chl, chlorophyll; FW, fresh weight; RWC, relative water } \\
\text { content; MDA, malondialdehyde } \\
{ }^{*} \text { Mean } \pm S D \text { of three biological and technical replicates. } \\
\text { a } p<0.05 \text { versus control } \\
{ }^{\circ} p<0.01 \text { versus control }\end{array}$} \\
\hline
\end{tabular}

Table 2. Changes in morpho-physiological parameters in Lens culinaris cultivar Sultan

\begin{tabular}{|c|c|c|}
\hline Parameters & Control & $\begin{array}{c}7^{\text {th }} \text { day stressed } \\
\text { group }\end{array}$ \\
\hline Plant height $(\mathrm{cm})$ & $31.3 \pm 0.14$ & $20.5 \pm 0.15^{\mathrm{a}}$ \\
\hline RWC (\%/plant) & $85.22 \pm 0.41$ & $60.23 \pm 0.36^{a}$ \\
\hline $\mathrm{Chl} \mathrm{a}(\mu \mathrm{g} / \mathrm{g} \mathrm{FW})$ & $2.68 \pm 0.04$ & $2.01 \pm 0.05^{\mathrm{a}}$ \\
\hline $\mathrm{Chl} \mathrm{b}(\mu \mathrm{g} / \mathrm{g} \mathrm{FW})$ & $5.98 \pm 0.34$ & $4.01 \pm 0.28^{a}$ \\
\hline Proline content ( $\mu \mathrm{mol} / \mathrm{g} \mathrm{FW})$ & $0.31 \pm 0.26$ & $5.51 \pm 0.41^{\mathrm{a}}$ \\
\hline $\mathrm{H}_{2} \mathrm{O}_{2}$ content $(\mu \mathrm{mol} / \mathrm{g} \mathrm{FW})$ & $0.017 \pm 0.37$ & $0.86 \pm 0.26^{a}$ \\
\hline MDA content $(\mu \mathrm{mol} / \mathrm{g} \mathrm{FW})$ & $4.42 \pm 0.05$ & $7.12 \pm 0.12^{\mathrm{a}}$ \\
\hline \multicolumn{3}{|c|}{$\begin{array}{l}\text { All the measured parameters from leaf samples of control and } \\
\text { experimental group plants grown for } 7 \text { days under drought stress are } \\
\text { given below. Chl, chlorophyll; FW, fresh weight; RWC, relative water } \\
\text { content; MDA, malondialdehyde } \\
{ }^{*} \text { Mean } \pm \text { SD of three biological and technical replicates. } \\
{ }^{a} p<0.01 \text { versus control }\end{array}$} \\
\hline
\end{tabular}

Table 3. Changes in morpho-physiological parameters in Lens culinaris cultivar Çiftçi

\begin{tabular}{|c|c|c|}
\hline Parameters & Control & $\begin{array}{c}7^{\text {th }} \text { day stressed } \\
\text { group }\end{array}$ \\
\hline Plant height $(\mathrm{cm})$ & $24.9 \pm 0.17$ & $19.24 \pm 0.17^{\mathrm{a}}$ \\
\hline RWC (\%/plant) & $84.22 \pm 0.11$ & $82.24 \pm 0.15$ \\
\hline $\mathrm{Chl} \mathrm{a}(\mu \mathrm{g} / \mathrm{g} \mathrm{FW})$ & $3.08 \pm 0.09$ & $3.12 \pm 0.07$ \\
\hline $\mathrm{Chl} \mathrm{b}(\mu \mathrm{g} / \mathrm{g} \mathrm{FW})$ & $3.78 \pm 0.07$ & $3.52 \pm 0.06$ \\
\hline Proline content $(\mu \mathrm{mol} / \mathrm{g} \mathrm{FW})$ & $0.365 \pm 0.22$ & $3.95 \pm 0.28^{b}$ \\
\hline $\mathrm{H} 2 \mathrm{O} 2$ content $(\mu \mathrm{mol} / \mathrm{g} \mathrm{FW})$ & $0.012 \pm 0.19$ & $0.014 \pm 0.13$ \\
\hline MDA content $(\mu \mathrm{mol} / \mathrm{g} \mathrm{FW})$ & $5.63 \pm 0.06$ & $5.82 \pm 0.16$ \\
\hline \multicolumn{3}{|c|}{$\begin{array}{l}\text { All the measured parameters from leaf samples of control and } \\
\text { experimental group plants grown for } 7 \text { days under drought stress are } \\
\text { given below. Chl, chlorophyll; FW, fresh weight; RWC, relative water } \\
\text { content; MDA, malondialdehyde } \\
{ }^{*} \text { Mean } \pm \text { SD of three biological and technical replicates. } \\
{ }^{a} p<0.05 \text { versus control. } \\
{ }^{b} p<0.01 \text { versus control. }\end{array}$} \\
\hline
\end{tabular}

in the stressed group did not show any significant differences when compared to control. A similar trend was observed when comparing $\mathrm{MDA}, \mathrm{H}_{2} \mathrm{O}_{2}$, and chlorophyll $a / b$ contents. The proline content of the plants in the $7^{\text {th }}$ day stressed group showed a significant increase when compared to control $(b p<0.01)$ (Table 1).

Sultan cultivar showed significant differences in all parameters (Table 2). Drought-stressed plants showed a significantly increased growth compared to control $\left({ }^{\mathrm{a}} \mathrm{p}<0.01\right)$. The relative water and the chlorophyll $a / b$ contents of the leaves in the stressed group decreased significantly compared to control $\left({ }^{\mathrm{a}} \mathrm{p}<0.01\right)$. The proline, MDA, and $\mathrm{H}_{2} \mathrm{O}_{2}$ contents of the leaves significantly increased in the $7^{\text {th }}$ day stressed group when compared to control $\left({ }^{\mathrm{a}} \mathrm{p}<0.01\right)$.

Çiftçi cultivar showed a similar response to that of Fırat 87 (Table 3). The only difference was observed in the plant height and the proline content of the plants in the $7^{\text {th }}$ day stressed group when compared to control, respectively $\left({ }^{a} p<0.05\right)\left({ }^{b} p<0.01\right)$. There was no significant difference in MDA, $\mathrm{H}_{2} \mathrm{O}_{2}$, and chlorophyll $a / b$ contents and RWC ratio.

Comparisons between the parameters of the cultivars showed that while the RWC ratio in the cultivars Çiftçi and Fırat 87 did not change (5\%), the ratio in the Sultan cultivar changed by $30 \%$. All the three cultivars showed an increase in proline accumulation, indicating a tolerance mechanism to drought stress. The Sultan cultivar showed $5.5 \%$ more proline accumulation than Firat 87 and Çiftçi cultivars. The Sultan cultivar also showed a significant increase in other parameters such as eight times higher MDA and four times higher $\mathrm{H}_{2} \mathrm{O}_{2}$ contents compared to that of other cultivars. This suggests that the cultivars Çiftçi and Fırat 87 may endure the proline accumulation against the drought but the cultivar Sultan required other physiological parameters rather than proline to cope with the stress.

\section{DISCUSSION}

Plants encounter various stress conditions during its life cycle. Significant negative effects occur to the development, metabolism, and yield of plants that undergo stress. Drought, inadequate nutrition, salinity, low and high temperatures, soil and atmospheric pollution, radiation are some of the abiotic stresses that limit the rate of vegetative production (18). Among the abiotic stresses mentioned, drought is the most important parameter that limits crop production. Plants experience drought stress when their roots do not get enough water or the transpiration rate is too high. There can be important differences in the cultivars of the same plant species and in their tolerance to drought (2). In the current study, the three lentil cultivars that were investigated exhibited different responses to drought stress. Our study indicates that there can be a wide variation in tolerance to drought stress among the lentil cultivars that can be exploited in breeding new cultivars demonstrating higher drought tolerance.

The first and most important effect of drought is degraded germination (19). Drought stress significantly reduces germination 
and seedling growth. Moreover, in alfalfa (Medicago sativa), germination potential, hypocotyl length, and (fresh and dry) shoot and root weights were reduced by PEG-induced water deficit, while the root length increased (20). Drought stress is characterized by reduced water content, diminished leaf water potential and turgor loss, closure of stomata and decrease in cell enlargement and growth (21). In the current study, we observed that 7 days after application of drought stress, the Sultan cultivar showed significant turgor loss than that of Çiftçi and Firat87 cultivars.

Proline content is linked to plant age, leaf age, leaf position, or leaf part. It is well known that proline manipulates protein improvement and sustains the quaternary structure of complex proteins (22). Under drought stress, proline accumulation correlates with stress tolerance in plants. Drought-resistant lentil cultivars have been reported to accumulate less proline than drought-sensitive species (23). Increased proline content in drought-stressed plants has been reported to be less in drought-tolerant types (22). Although Oktem et al. (24) have not observed a significant change in proline content in root and shoot tissues under drought stress, our results indicate that proline accumulation does occur under drought stress in the leaves of lentil varieties, which are consistent with the results of previous studies $(8,10,25,26,27)$. Our results also indicate that the rate of photosynthesis and water potential of leaves and flowers decrease under drought stress, which are similar to the results of Liu et al. (28).

It has been reported that higher $\mathrm{H}_{2} \mathrm{O}_{2}$ accumulation under drought and other abiotic stresses is more common in sensitive chickpea cultivars (29). Measurement of $\mathrm{H}_{2} \mathrm{O}_{2}$ in plant tissues under stress conditions can give strong evidence of the extent of oxidative damage because $\mathrm{H}_{2} \mathrm{O}_{2}$ serves as a precursor of highly reactive species (24). In this study, it was observed that the $\mathrm{H}_{2} \mathrm{O}_{2}$ content in lentil cultivars increased due to drought stress and the amount was significantly higher in the cultivar Sultan than in Fırat 87 and Çiftçi cultivars. This suggests that the low $\mathrm{H}_{2} \mathrm{O}_{2}$ content in the Fırat 87 and Çiftçi cultivars may be due to the effective reactive oxygen species (ROS) scavenging mechanism in these cultivars. ROS causes lipid peroxidation and is measured in terms of MDA content (22). MDA levels in plants are often used as a marker of oxidative damage. In our study, the lipid peroxidation (MDA content) of the Sultan cultivar was higher than the other cultivars. Our findings are consistent with early findings in chickpea (29) and lentil (30). From the results of the current study, it can be concluded that there is a direct relationship between $\mathrm{H}_{2} \mathrm{O}_{2}$ accumulation and lipid peroxidation under drought stress in lentils. The high $\mathrm{H}_{2} \mathrm{O}_{2}$ and MDA contents of the Sultan cultivar showed that drought stress caused more damage to the Sultan cultivar than those of the Firat 87 and the Çiftçi cultivars.

The amount of chlorophyll $a / b$ is indicated as a potential measure against drought stress in peanuts (31) and pigeon pea (32). Chlorophyll $a / b$ amount indicates the stress susceptibility of chlorophyll molecules. Chlorophyll helps to maintain the life of the plant with better usability (33).Drought is considered to be a desirable parameter for sustaining the rate of photosynthesis for high yielding cultivars and for selecting resistant species (34). Our results of this study showed that there was no explicit change in the chlorophyll $a / b$ content of Fırat 87 and Çiftçi cultivars but a decrease in the Sultan cultivar, which is similar to the results of previous studies (31-33).

Plants in drought stress conditions often have various physiological adaptations, and these adaptations are directly related to the resistance mechanism (35). Under drought stress conditions, the resistance mechanism becomes even more complex because the susceptibility of some responses is highly dependent on plant species, stress intensity, and stress evolution (34). As a result of our study, Fırat87 and Çiftçi cultivars can be accepted as drought-resistant cultivars when compared to the cultivar Sultan.

\section{REFERENCES}

1. Coskuner Y, Karababa E. Production Potential and Processing Technology of Lentil in Turkey. Gıda 1998; 3: 201-9.

2. Kumar S, Rajendran K, Kumar J, Hamwieh A, Baum M. Current knowledge in lentil genomics and its application for crop improvement. Front Plant Sci 2015; 6: 78. [CrossRef]

3. Srivastava RP. Vasishtha H. Saponins and lectins of Indian chickpeas (Cicer arietinum) and lentils (Lens culinaris). Indian J Agric Biochem 2012; 25(2): 44-7.

4. Lawlor DW, Cornic G. Photosynthetic carbon assimilation and associated metabolism in relation to water deficits in higher plants. Plant Cell Environ 2002; 25(2): 275-94. [CrossRef]

5. Foyer $\mathrm{CH}$, Noctor $\mathrm{G}$. Tansley Review No. 112. Oxygen processing in photosynthesis: regulation and signalling. New Phytologist 2012; 112: 359-88.

6. Peltzer DE, Dreyer E, Polle A. Differential temperature dependencies of antioxidative enzymes in two contrasting species: Fagus sylvatica and Coleus blumei. Plant Physiol Biochem 2002; 40(2): 141-50. [CrossRef]

7. Sairam RK, Deshmukh PS, Saxena DC. Role of antioxidant systems in wheat genotypes tolerance to water stress. Biol Plantarum 1998; 41: 387-94. [CrossRef]

8. Khan AJ, Hassan S, Tariq M, Khan T. Haploidy breeding and mutagenesis for drought tolerance in wheat. Euphytica 2001; 120(3): 409-14. [CrossRef]

9. Singh D, Singh CK, Tomar RS, Taunk J, Singh R, Maurya S, et al. Molecular assortment of Lens species with different adaptations to drought conditions using SSR markers. PLoS One 2016; 11(1): e0147213. [CrossRef]

10. Steward CR, Hanson AD. Proline Accumulation as a Metabolic Response to Water Stress. In Adaptation of Plant to Water and High Temperatures Stress' Wiley. 1980; 173-89.

11. Tan BH, Halloran GM. Variation and correlations of proline accumulation in spring wheat cultivars. Crop Sci 1980; 22(3): 459-63. [CrossRef]

12. Hoagland DR, Arnon DI. Growing plants without soil by the water-culture method. Circ. Calif Agric Exp Stn 1938.

13. Dhanda SS, Sethi GS. Inheritance of excised-leaf water loss and relative water content in bread wheat (Triticumastivum). Euphytica 1998; 104: 39-47. [CrossRef]

14. Arnon DI. Copper enzymes in isolated chloroplasts. Polyphenoloxidase in Beta vulgaris, Plant Physiol 1989; 24(1): 1-15. [CrossRef] 
15. Sairam R. K, Saxena, D. C. Oxidative stress and antioxidants in wheat genotypes: possible mechanism of water stress tolerance. J Agron Crop Sci 2000; 184(1): 55-61. [CrossRef]

16. Bates L. S, Waldren R. P, Teare I. D. Rapid determination of free proline for water-stress studies. Plant Soil 1973; 39(1): 205-7. [CrossRef]

17. Teranashi Y, Tanaka A, Osumi M, Fukui S. Catalase activity of hydrocarbon utilizing candida yeast. Agric Biol Chem 1974; 38: 1213-6. [CrossRef]

18. Allen RD. Dissection of oxidative stress tolerance using transgenic plants. Plant Physiol 1995; 107(4): 1049-54. [CrossRef]

19. Harris D, Tripathi RS, Joshi A. On-farm seed primingto improve crop establishment and yield in dry direct seeded rice, in: Pandey S, Mortimer M, Wade L, Tuong TP, Lopes K, Hardy B. (Eds.), Direct seeding: Research Strategies and Opportunities, International Research Institute, Manila, Philippines, 2002; 1: 231-40.

20. Zeid IM, Shedeed ZA. Response of alfalfa to put rescine treatment under drought stress. Biol Plant 2006; 50: 635-40. [CrossRef]

21. Jaleel CA, Manivannan P, Wahid A, Farooq M, Somasundaram R, Panneerselvam R. Drought stress in plants: a review on morphological characteristics and pigments composition. Int J Agric Biol 2009; 11: 100-5.

22. Bandeoglu E, Eyidogan F, Yucel M, Oktem AH. Antioxidant responses of shoot and root of lentil to $\mathrm{NaCl}$-salinity stress. Plant Growth Regul 2004; 42: 69-77. [CrossRef]

23. Mishra BK, Srivastava JP, Lal JP. Drought stress resistance in two diverse genotypes of lentil (Lens culinarisMedik.) imposed at different phenophases. J Food Legume 2014; 27(4): 307-14.

24. Oktem HA, Eyidooan F, Demirba D, Bayrac AT, Oz MT, Ozgur E. Antioxidant responses of lentil to cold and drought stress. J Plant Biochem Biotechnol 2008; 17: 15-21. [CrossRef]

25. Erakar S, Murumkar C. Proline accumulation in Tephrosiapurpurea pers. Biologia Plantarum 1995; 37: 301-4. [CrossRef]

26. Muscolo A, Sidari M, Anastasi U, Santonoceto C, Maggio A. Effect of PEG-induced drought stress on seed germination of four lentil genotypes. J Plant Interact 2014; 9: 354-63. [CrossRef]
27. Talukdar D. Comparative morpho-physiological and biochemical responses of lentil and grass pea genotypes under water stress. J Nat Sci Biol Med 2013; 4(2): 396-402. [CrossRef]

28. Liu HP, Dong BH, Zhang YY, Liu ZP, Liu YL. Relationship between osmotic stress and the levels of free, soluble conjugated and insoluble-conjugated polyamines in leaves of wheat seedlings. Plant Sci 2004; 166: 1261-7. [CrossRef]

29. Gunes A, Inal A, Adak MS, Bagci EG, Cicek N, Eraslan F. Effect of drought stress implemented atpre- or post-anthesis stage on some physiologicalparameters as screening criteria in chickpea cultivars. Russ J Plant Physiol 2008; 55: 59-67. [CrossRef]

30. Chakraborty U, Pradhan D. High temperatureinduced oxidative stress in Lens culinaris role of antioxidantsand amelioration of stress by chemical pretreatments. J Plant Interact 2011; 6: 43-52. [CrossRef]

31. Arunyanark A, Jogloy S, Akkasaeng C, Vorasoot N, Kesmala T, Nageswara RC, et al. Chlorophyll stability is an indicator ofdrought tolerance in peanut. J Agron Crop Sci 2008; 194: 113-25. [CrossRef]

32. Singh AK, Srivastava JP, Singh RM, Singh MN, Kumar M. Selection parameters for pigeonpea (Cajanus cajanL. Millsp.) genotypes at early growthstages against soil moisture stres. J Food Legume 2013; 26: 97-102.

33. Kumar SM, Ponnuswami V. Effect of different water regimes and organic manures on indole acetic acid (IAA), oxidase activity, leaf area, light transmission ratio, chlorophyll stability index, relative water content and yield attributes of noni (Morinda citrifolia L.). J Med Plant Res 2015; 9: 550-60.

34. Mishra BK, Srivastava JP, Lal JP. Drought stress resistance in two diverse genotypes of lentil (Lens culinaris Medik.) imposed at different phenophases. J Food Legume 2014; 27: 307-14.

35. Shrestha R, Turner C, Siddique M, Turner DW. Physiological and seed yield responses to water deficit among lentil genotypes from diverse origins. Aust J Agric Res 2006; 57: 903-15. [CrossRef] 